\title{
English language instructors' beliefs about the role of L1 in English language development and formal instruction in Croatia: A survey
}

\author{
Mirna Erk \\ Faculty of Education \\ University of Osijek
}

\begin{abstract}
Current understanding of second language acquisition processes is based on the position that second language learners rely and depend on their L1 as well as on all of their language-related experience. This paper presents results of a questionnaire study aimed to explore Croatian EFL instructors' beliefs about the role of L1 in English language development and formal instruction. Data was further analysed in order to explore variables most likely to impact instructors' belief systems (participants' age and academic degree, students' language level, learning setting). The findings point to a lack of professional consensus with regard to L1 use which is discussed and followed by practical implications.
\end{abstract}

Key words: foreign language instructors; EFL development; L1 role; FL instruction.

\section{Introduction}

Contributions of previous language learning experience and language knowledge to the development of skills in a new language have gained attention from those involved in the theoretical and applied discipline of SLA. Since the early 1990s, previous language-related experience, notably knowledge of one's L1, has been treated less as an inconvenience and more as a welcomed resource for the process of learning and teaching another language (e.g. Cook, 1997, 2001; Cummins, 2001, 2007). This stands in sharp contrast to the monolingual assumption (Hall \& Cook, 2012) which had been promoted worldwide as the best instructional policy for successful SLA 
since the late 19 th century and well into the 20th century. The study presented in this paper aims to reveal if a monolingual approach to foreign language teaching is an applied language policy at the primary, secondary and tertiary level of EFL education in the Republic of Croatia. In order to do so the study addresses the most significant stakeholder of the policy implementation: the foreign language teacher. More precisely, the research at hand addresses the issue of foreign language instructors' beliefs about the benefits of L1 use in the process of learning and teaching English to L1 speakers of Croatian.

\section{The role of $\mathrm{L} 1$ in $\mathrm{L} 2$ development}

Thanks to the sharp turn in the understanding of how the human mind in interaction with its environment uses all available language experience to make and interpret meaning, a door has been opened for the study of language ability development which recognizes the existence and the dynamic interplay of more languages in the mind of L2 speakers (see Cook, 2008; Herdina \& Jessner, 2002; Kramsch, 2002; Larsen-Freeman, 1997). Hence, the negative impact of prior language ability on new language development is being pushed out from the focus of interest in order to provide room for a positive contribution of L1 in L2 development. The new position highlights rather than ignores L2 learners' linguistic background and experience in an effort to explain processes, mechanisms and outcomes of SLA. Before we embark on the consequences of this change, let us take a closer look at the circumstances and interpretations of L1's role that paved the way for this new understanding.

\subsection{The traditional view of the role of $L 1$ in $L 2$ development}

Traditionally, SLA research overlooked the learners' L1 or treated it as a threat to target language input and use (e.g. Turnbull, 2001), especially in foreign language instructional contexts where a limited amount of time and language input are available for L2 learning (Muñoz, 2008). This was probably due to the perpetual insistence of many linguists throughout most of the $20^{\text {th }}$ century that L1 had a negative influence on L2 development and, their recommendation to ignore the features of any language(s) known to the learner (Hall \& Cook, 2012). Lack of success or error-free L2 acquisition was attributed to the L1 interference, and the remedy was found in the contrastive analysis hypothesis and the assumption that by detecting differences and similarities between languages the negative transfer from L1 would be prevented and the positive transfer reinforced. Unfortunately, the assumed 
positive L1 transfer in SLA remained marginally researched until the last decade of the $20^{\text {th }}$ century.

Persistent political and social understandings and historical circumstances have also contributed to the widely held monolingual attitudes about L2 instruction, such as ideas about one language-one country-one nation (Auer \& Wei, 2007; Auerbach, 1993; Wagner, 2018), linguistic purism and the fear of contamination of one language by others (e.g. Wei, 2018), all of which have led to the perceptions that switching between languages or mixing them is inappropriate and unacceptable in any given context, even more so in the context of formal education. Moving between languages in an educational setting was traditionally seen as unwanted behaviour lacking institutional endorsement or pedagogical underpinning (Creese \& Blackledge, 2010). The best example is that of bilingual education where strict separation of two languages used to be a norm (Jacobson \& Faltis, 1990).

The heavy focus on the negative influence of L1 on L2 acquisition was reflected in language education policy: in instructional settings teachers were strongly advised to avoid using L1 (Cook, 2010) and adhere to the Englishonly or TETE policy (Phillipson, 1992). Instructional principles in settings where English was taught as the second language were transferred to foreign language classrooms without reservation, even though learning/teaching conditions and expected outcomes in these two types of settings seem to be quite different (see Muñoz, 2008). In addition, the monolingual principle was supported by popular methods of the time that insisted on exclusive target language use (e.g. the Berlitz Method, the ALM, the TPR Method), and by monolingual L2 textbooks sold worldwide. It is no surprise that literature dealing with the observed, but frowned upon, use of L1 in L2 and FL instruction refers to L1 in instructional settings as to a "bone of contention" (Gabrielatos, 2001), "a taboo subject" (Hitotuzi, 2006), and a "skeleton in the closet" (Prodromou, 2000), to name just a few telling descriptions. In this sense, whenever L1 would find its way into an L2 classroom it lead teachers to feel embarrassment, (Hitotuzi, 2006) guilt, or inadequacy (Auerbach, 1993; Mitchell, 1988).

\subsection{New developments in SLA on the role of L1in L2 development}

It seems that several parallel developments in SLA theory called into question the belief of the superiority of target language exclusivity in the language classroom. On the one hand, the multilingual turn initiated by Cook back in 1991, which conceptualises language learning as a multilingual practice (Meier, 2016), brought along or re-established concepts starting with multi and cross into the foreground of SLA researchers' interest (e.g. multi- 
lingual practice, multicompetence, multilingual development, crosslinguistic influence, cross-linguistic awareness, cross-linguistic interaction, cross-linguistic transfer, etc.). Additional conceptualizations of this new interest are exemplified by the introduction of more and more concepts into the relevant literature, e.g. metrolingualism, polylanguaging, polylingual languaging, heteroglossia, code meshing, translingual practice, flexible bilingualism, multilanguaging, and hybrid language practices (Lewis et al, 2012). Finally, current trends seem to support concepts prefixed with trans, such as translingual competence (Canagarajah, 2013), translingual practice (Canagarajah, 2014) and translanguaging (e.g. Creese \& Blackledge, 2010; Wei, 2018), all of which share the idea that multilinguals use their holistic linguistic repertoire to communicate effectively. It seems that, at least in the SLA theory, mono has been stepping away due to the raising awareness of the need to look at language in a more dynamic, integrated/crosslingual way (Meier, 2016).

It is believed that there are more bilingual and multilingual people in the world than there are monolinguals (Tucker, 1999). Hence, interest in the languages a new language learner already knows as well as importance and impact of this knowledge for new language acquisition should be at the heart of research on the development of knowledge and skills in any new language, a view that stands in contrast to the traditional monolingual approach to language acquisition. Current understandings of the ways human minds operate support the idea that languages exist alongside each other in one's mind and any effort at keeping them apart is fruitless and/or detrimental to the natural disposition of the brain (see Cummins, 1979; Kroll et al, 2013; Lowie et al, 2014).

What provides further support of the importance L1 plays in SLA is the social turn (Firth \& Wagner, 1997) which pointed researchers' interest at the social practice in which language is used and learned. In instructional settings this practice provides plentiful evidence of both student and teacher code-switching which is a shared behaviour and a resource that contributes positively to new language development and creation of better conditions for learning (e.g. Butzkamm, 2003; Lantolf, 2000; Levine, 2011).

The number of sister disciplines and different orientations within SLA (e.g. sociolinguistics, neurolinguistics, psycholinguistics, socio-cultural theorists, socio-cognitive theorists, complexity theorists, traditional research on bilingualism) that provide theoretical or empirical support for the notion that all learner's languages contribute in the construction of new language knowledge is ever-increasing. It is fair to say that recent developments in SLA assign a central role to FL learners' L1 in this process, most notably the multilingual turn (May, 2013) and the understanding of a complex and dy- 
namic nature of (any) language acquisition (Beckner et al, 2009; De Bot et al, 2007; Herdina \& Jessner, 2002; Larsen-Freeman, 1997).

The alternative understanding of the role of previously known languages (especially learner's L1) may come as no surprise to those who have always advocated for the English-mostly approach in ELT and recognized that a role for L1 in SLA theory has been unfairly neglected (e.g. Atkinson, 1987; Butzkamm, 2003; Cohen, 1998; Cook, 1997; Ellis, 1994; Macaro, 2001; Turnbull, 2001 and many others). Thanks to these voices, research on L1 in SLA has always managed to find its way into print media, no matter how marginalized. The empirical evidence on the presence and contributing influence of L1 on better new language acquisition is described in the next section of this paper. The emphasis is put on the research directly relevant for the study that follows, i.e. studies on instructors' beliefs about L1 role in instructed SLA (further: ISLA, following Ellis, 2000).

\section{Research into the role of L1 in ISLA}

As classroom research points at language alternation as a commonly observed phenomenon (Iyitoglu, 2016), quite a lot of research has been done on the role of L1 in ISLA up till today. However, it has been conducted in settings and under conditions which are very different and, as such, might have a bearing on results and make comparisons between findings difficult or, sometimes, unjustified. For example, research on the role of L1 in instruction which takes place in L2 settings, where the target language input is readily available within and beyond the school setting, is hardly comparable to research into the role of L1 in minimal input situations of foreign language learning contexts (Larson-Hall, 2008) where absence of availability of the target language in wider social context makes demands on classroom interaction which are quite different from those in L2 settings. Also, methodology applied in researching L1 in ISLA is extremely varied in terms of the age and choice of participants, formal instructional features (e.g. the amount of classroom time available for L2 instruction, class sizes, instructors' educational background, learners' level of L2 competence, etc.), and instruments applied (e.g. there is a variety of qualitative or quantitative tools and protocols that include different choices with respect to units of language analysis, use of (in)validated questionnaires, interview forms, etc.), all of which calls for careful interpretation of findings, especially when it comes to issuing recommendations for educational practice.

Empirical investigations on the role of L1 in ISLA can be roughly divided into three different lines of research. One of them focuses on the relationship between classroom L1 use and student lexical and grammatical knowledge, 
strategy use and development of metaphorical competence, and provides proof of a positive L1 contribution (e.g. Hall \& Cook, 2012; Ho Lee \& Macaro, 2013; Macaro, 2009).

Another line deals with the presence or absence of L1 in classroom interaction and the functions it fulfils from the perspective of instructors and students. Both participants of classroom interaction employ L1 as a psychological tool that ensures comprehension but students also use it for cooperation when organizing shared tasks and activities (e.g. Antón \& DiCamilla, 1999; Ma, 2016; Swain \& Lapkin, 2000; Schmitt, 1997). Teachers tend to use it for different but mostly overlapping functions that are closely related to the teaching of vocabulary and grammar, translation, classroom management and affective aspects of classroom interaction (e.g. Guthrie, 1984; Hall \& Cook, 2013; Iyitoglu, 2016; Kim \& Elder, 2005; Lin, 1990; Milk, 1982, 1984). As for the quantity of L1 use across classrooms, the findings point at highly variable extent of instructors' L1 use in classroom discourse, ranging from no use (e.g. Duff \& Polio, 1990; Rolin-Ianziti \& Brownlie, 2002) to 94\% of L1 use (e.g. Nagy, 2009; Radišić, 2013). The high amount of L1 use rightfully calls into question the promise of the development of communicative competence through formal instruction when the dominant language of classroom discourse is the learners' L1. What is more, teachers are found to underestimate their L1 use (Nikolov \& Mihaljević Djigunović, 2011; Polio \& Duff, 1994). Although there have been attempts to establish a link between teacher proficiency and L1 use, research findings to date are inconsistent (Carless, 2004; Bateman, 2008; Kim \& Elder, 2005; Nagy \& Robertson, 2009; Rolin-Ianziti \& Brownlie, 2002; Crawford, 2004; Raschka et al, 2009).

The third line of research on L1 in ISLA is about beliefs about L1 use in learning and teaching. Attitudes to the importance or lack of importance of L1 in instructed contexts are investigated from the perspective of those teaching the language and those learning it. It is interesting to note that students' rather than instructors' attitudes seem to be more readily investigated.

In studies dealing with student attitude to L1 use the belief that L1 should be used as a learning and, when necessary, communication strategy because it facilitates comprehension which, in turn, leads to better learning is widely shared (e.g. Burden, 2000; Chavez, 2003; Dujmović, 2007; Ferrer, 2002; Janulienè, 2008; Kelleher, 2013; Levine, 2003; Macaro, 1997; Nazary, 2008; Paker \& Karaağaç, 2015; Prodromou, 2000; Schweers, 1999; Shimizu, 2006; Tang, 2002). Next, only the most advanced students accept exclusive target language use, which supports the notion of a threshold level of target language competence needed for the learner to be able to think in the target language without recourse to their L1 (Cohen, 1998). Further support for the same notion is provided by a shared recognition of student participants in a 
number of studies that not enough of L1 can cause confusion and anxiety, whereas too much of it is a threat to optimal language progress. Hence it seems safe to conclude that research on students' attitude to L1 use in L2 classrooms points to their admirable awareness of an important role of L1 in ISLA.

Instructors' beliefs about L1 use in L2 teaching are derived from their experience as language learners, their language education and training and language teaching experience, but also through other colleagues, teacher trainers and educators, policy-makers and academic research and researchers. The overall findings of research on teacher beliefs (e.g. Dickson, 1996; Ferrer, 2002; Nakayama, 2002; Schweers, 1999; Shimizu, 2006; Tang, 2002) show that teachers believe L1 use to be most affected by learner L2 ability (e.g. Crawford, 2004; Macaro, 1997; Mitchell, 1988; Littlewood \& Yu, 2011). Although they are reluctant to admit to using it, they believe that L1 is beneficial for the student-teacher relationship. However, they refuse to use L2 for teaching grammar, as well as to explain difficult vocabulary - for this purpose the teachers find L1 appropriate and useful (e.g. Mitchell, 1988).

Studies about attitude towards L1 in ISLA are usually operationalised through a questionnaire consisting of belief statements and/or open and close-ended questions. However, data about the validity of instruments applied is often missing and more often than not they seem not to be subjected to rigorous statistical analysis (e.g. Schweers, 1999; Shimizu, 2006; Tang, 2002). As beliefs about SLA are most commonly elicited via questionnaires with Likert-scale alternatives, the study adopted the same design that led to quantitative data collected via a survey.

\section{Croatian language instructors' beliefs about the benefits of L1 in EFL instruction}

Foreign language instructors' beliefs about ISLA are an important psychological construct since a great amount of literature indicates that they significantly influence implementation of teaching approaches, techniques and activities (e.g. Barcelos, 2003; Bernat, 2007; Borg, 2003; Pajares, 1992; Peacock, 2001). From this angle, knowledge about FL instructors' belief systems could help improve their professional training and education, as well as the effectivenes of their teaching. The rationale for the study that follows was found in the assumption that beliefs about the role of L1 in formal learning of foreign languages have consequences for teacher behaviour and personal decisions about lesson planning and classroom practices related to L1 and target language use. Hence, the focus placed on EFL instructors is justified by the fact that their work embodies the connection between SLA models and re- 
search and classroom practice. Many argue today for a tolerant approach to L1 use in ISLA that utilizes its positive potential for FL development (RolinIanziti, 2003). To the best of our knowledge, cross-sectional research that focuses on EFL instructors' beliefs about contributions of L1 in EFL study has not been conducted in the Croatian socio-educational context, except in the Kovačić \& Kirinić (2011) study with the narrow focus on the use of L1 in tertiary ESP courses. The present study attempts to fill that void.

\subsection{Aim and research questions}

The aim of the study was to explore English language instructors' beliefs about L1 use in EFL development and formal instruction. More specifically, the goal was to find out if Croatian EFL instructors attribute a positive role to the L1 in their formal teaching practice. With this aim in mind EFL instructors were invited to respond to a set of belief statements about the benefits of L1 use in formal instruction based on current theory and research of second language acquisition. To this end, the following research questions (RQ) were formulated:

RQ1. Do EFL instructors in Croatia use their learners' L1 in language classes and how frequently across different education levels?

RQ2. Is there a relationship between the reported frequency of instructors' L1 use and their attitude to L1 role in FL formal learning settings?

RQ3. To what extent do EFL instructors agree on positive contributions of L1 use in FL development and formal instruction?

RQ4. Is the instructors' attitude to L1 role in FL formal learning setting influenced by their age, teaching experience, instructional setting and/or learner ability?

Taking these questions as starting points, various benefits of L1 use in ISLA were identified for inclusion in the study. They were based on current theoretical positions and research findings reviewed in the theoretical part of this paper.

\subsection{Research context}

The study was conducted in the context of a uniform setting, teacher profile, learners' L1 background and language policy. The setting is that of teaching English as the first foreign language (explained below in more detail), all instructors are non-native English teachers, learners and teachers share the same L1 (Croatian), and the official language policy is to maximize foreign and minimize first language use in formal instruction. Croatian primary education takes 8 years, whereby lower primary level stands for grades 1-4 
and upper-primary level for grades 5-8. This is followed by secondary education, in vocational schools (3 or 4 years) or grammar schools (4 years). Primary and secondary education is mandatory. Upon their completion, there is a wide choice of university courses of study of either academic or professional orientation and various polytechnic institutes and colleges which cater for tertiary education, some offered by private providers (outside the state-funded university realm).

In the Croatian context of teaching English as the first foreign language, where foreign language learning starts in Grade 1 and continuity is ensured, the next educational stage usually means that the foreign language ability of students increases. Hence, secondary students' FL ability is higher than primary students' ability and the highest ability is expected at university courses of study aimed at education and training of prospective English teachers and interpreters. However, foreign language ability of students in vocational secondary schools may be different than those attending grammar schools, due to differences in programme aims, content and intensity, background knowledge, and FL ability level before starting secondary education as well as socioeconomic background.

In the Croatian education system there are marked differences in language aims, contents and practices in language courses aimed at teaching young vs. older learners, students in grammar vs. vocational schools, and prospective English teachers vs. non-English students. For example, students in vocational secondary schools receive ESP instruction whereas grammar school students receive general English language instruction (see more in Pavičić Takač \& Berka, 2014). Likewise, prospective English teachers attend courses of study quite different from those offered to students of other departments who, in addition, may be quite heterogeneous with respect to their language ability. Since beliefs about SLA are context-bound and dynamic (Barcelos, 2003), different aspects of these academic settings are incorporated into the interpretation of the study findings.

Another important feature of Croatian foreign language learning context is that first foreign language study starts in Grade 1. Many students start learning a second foreign language in primary school already (usually in Grade 4). The most common second foreign language is German, followed by Italian and French. Given that almost half of the primary school population who start learning English in Grade 1 chooses to study German as a second FL in Grade 4, opportunities for cross-linguistic and cross-cultural enrichment of FL instruction are provided along with a recognition of FL classroom's potential as a multilingual community of practice. 


\subsection{Sample}

Demographic information about participants $(\mathrm{N}=440)$ was collected in the following areas: gender, age, qualification, setting, teaching level and school type (Table 1$)$.

Table 1. Demographic information about study participants.

\begin{tabular}{|l|l|r|r|}
\hline \multicolumn{2}{|l|}{ PARTICIPANTS' PROFILE $(\mathrm{N}=440)$} & $\mathrm{N}$ & $\%$ \\
\hline \multirow{2}{*}{ GENDER } & female & 415 & 94.3 \\
\cline { 2 - 4 } & male & 25 & 5.7 \\
\hline \multirow{3}{*}{$\begin{array}{l}\text { QUALIFICA- } \\
\text { TION }\end{array}$} & English majors (university degree) & 325 & 73.9 \\
\cline { 2 - 4 } & English minors (university degree) & 108 & 24.5 \\
\cline { 2 - 4 } & teacher academy & 1 & .2 \\
\cline { 2 - 4 } & non-qualified & 6 & 1.4 \\
\hline \multirow{4}{*}{ SETTING } & urban & 276 & 62.7 \\
\cline { 2 - 4 } & suburban & 75 & 17 \\
\cline { 2 - 4 } & rural & 88 & 20 \\
\hline \multirow{3}{*}{ TEACHING } & primary & 278 & 60 \\
\cline { 2 - 4 } LEVEL & secondary & 117 & 26.4 \\
\cline { 2 - 4 } & tertiary & 42 & 9.6 \\
\hline \multirow{4}{*}{ SCHOOL } & lower primary (grades 1-4) & 163 & 23 \\
\cline { 2 - 4 } & upper primary (grades 5-8) & 62 & 14.1 \\
\cline { 2 - 4 } & secondary - grammar school & 54 & 12.3 \\
\cline { 2 - 4 } & secondary - vocational school & 14 & 3.2 \\
\cline { 2 - 4 } & university - English language students & 28.4 \\
\cline { 2 - 4 } & university - other students & & \\
& & & 28 \\
\end{tabular}

Female language respondents $(94.3 \%)$ greatly outnumbered male respondents $(5.7 \%)$. With regard to the academic rank, a great majority of respondents had a university degree $(98.4 \%)$, only one respondent had a diploma from a teacher academy, and there were 6 respondents without qualification for foreign language teaching $(1.4 \%)$. The majority of respondents worked in urban schools (62.7\%), a fifth of them worked in rural (20\%) and somewhat less in suburban schools $(17 \%)$. Of all the respondents, a great majority worked in primary education $(60 \%)$, less than one third in secondary education $(26.4 \%)$, and the least amount at universities $(9.6 \%)$. Just a fraction of university respondents worked with trainee teachers of EFL $(3.2 \%)$, the rest $(6.4 \%)$ worked with students of other majors, non-language related. A greater number of respondents came from secondary grammar $(14.1 \%)$ and vocational schools $(12.3 \%)$. As mentioned above, the highest response rate came from the primary sector, with $23 \%$ from lower and $27 \%$ from upper primary classes. The participants' age and years of teaching 
experience varied greatly: they were between 24 and 64 years old $(N=439$, $\mathrm{M}=36.05, \mathrm{SD}=9.601)$ and they had from three months to 42 years of work experience in teaching $\mathrm{EFL}(\mathrm{N}=440, \mathrm{M}=11.14, \mathrm{SD}=18.891)$.

\subsection{Instrument and procedure}

There are positive and negative sides to L1 use. Since its negative influence was a dominant focus in L1-related research in mainstream SLA throughout the $20^{\text {th }}$ century, the instrument applied in this study was constructed with the specific aim of addressing positive contributions of L1 use. Prior to the study, a pen-and-paper pilot study was conducted with 215 primary teachers of English and German from three different counties in Croatia. The reliability coefficient was satisfactory $(\alpha=.807)$ and factor analysis pointed to one factor explaining $41.39 \%$ of the variance (Radišić, 2009). This resulted in the Beliefs about L1 use in foreign language instruction scale which was constructed with the specific aim to reveal if EFL instructors are aware of the advantages of L1 use.

The Beliefs about L1 in FL Instruction Scale (BL1FLI Scale) consists of eight belief statements motivated by current SLA theory and research findings regarding the role of L1 in ISLA (Table 2). The participants responded by expressing their degree of agreement to the statements ( 1 for strongly disagree $\rightarrow 5$ for strongly agree). The questionnaire also included a section for relevant demographic information and two questions: one about the perceived frequency of L1 use in English language classes (on the five-point scale ranging from never to always) and another about the perceived percentage of L1 use in FL lessons. Finally, there was additional space for participants to share their comments and/or remarks about the role of L1 in ISLA, if they wished. This was inserted with the aim of shedding more light on instructors' thoughts and feelings about the role of L1 in ISLA, i.e. it was believed that this qualitative information would lead to a more reliable interpretation of the study findings.

Table 2. Statements of the BL1FLI Scale.

\begin{tabular}{|ll|}
\hline \multicolumn{2}{|l|}{ Beliefs about L1 in FL Instruction Scale } \\
\hline 1. & L1 use contributes to better time management. \\
\hline 2. & L1 use makes learners feel more confident and comfortable. \\
\hline 3. & L1 use contributes to better understanding of vocabulary. \\
\hline 4. & L1 use contributes to the efficiency of my teaching. \\
\hline 5. & Learners have their L1 at the back of their mind anyway. \\
\hline 6. & L1 use contributes to longer retention of vocabulary. \\
\hline 7. & L1 use contributes to better understanding of grammar. \\
\hline 8. & L1 use helps learners learn English better. \\
\hline
\end{tabular}


The questionnaire was distributed online through a platform used by the Croatian Association of Teachers of English over a period of 6 months. Participation in the study was voluntary and anonymous, which by itself implies certain limitations of the survey that have to be acknowledged. However, it enabled cross-sectional collection of data from a large number of Croatian EFL instructors, which accords well with the aims of the study.

Statistical package SPSS 20 was used. Data were analysed via descriptive statistics, whereas relationships between variables were examined via inferential statistics (ANOVA, Pearson correlation). The perspective adopted is etic and quantitative.

\subsection{Results and discussion}

In this section the results are organized, presented and discussed in response to the research questions (RQ 1-4) outlined in section 4.1. in this paper.

\subsubsection{RQ1. Do EFL instructors in Croatia use their learners' L1 in lan- guage classes and how frequently across different education levels?}

Analysis of the data collected via an online questionnaire about benefits of L1 use in EFL instruction provided clear evidence that L1 is used (Table 3) in EFL classes across different educational stages $(\mathrm{N}=440, \mathrm{M}=3.15, \mathrm{SD}=.743)$. A great majority of instructors reported using L1 sometimes (53\%) or often $(27.3 \%)$. Not many use it rarely $(16.4 \%)$, and a small number reported using L1 always (2.7\%). Only three instructors (0.7\%) reported never using L1. Overall, the data show that Croatian instructors make use of their learners' L1 in their EFL classroom practice. This finding serves as further evidence against the legitimacy of the endeavour to deny the role of L1 in EFL instruction, as already suggested by research reviewed earlier in this paper.

Table 3. Descriptive data about reported frequency of L1 use in EFL instruction.

\begin{tabular}{|l|l|c|c|c|c|}
\hline Item & Scale & $\mathrm{N}$ & $\%$ & $\mathrm{M}$ & SD \\
\hline \multirow{4}{*}{$\begin{array}{l}\text { I use L1 in EFL } \\
\text { instruction. }\end{array}$} & never & 3 & 0.7 & & \\
\cline { 2 - 4 } & rarely & 72 & 16.4 & & \multirow{3}{*}{3.15} \\
\cline { 2 - 4 } & sometimes & 233 & 53.0 & .743 \\
\cline { 2 - 4 } & often & 120 & 27.3 & & \\
\cline { 2 - 4 } & always & 12 & 2.7 & & \\
\hline
\end{tabular}

The reported frequency of L1 use varies across different stages of education (Table 4). The participants teaching primary students reported using L1 
more than those teaching secondary students $(\mathrm{N}=282, \mathrm{M}=3.29, \mathrm{SD}=.676$ and $\mathrm{N}=119, \mathrm{M}=3.05, \mathrm{SD}=.759$ respectively) who, in turn, use L1 more than those working at university level $(\mathrm{N}=41, \mathrm{M}=2.44, \mathrm{SD}=.709)$. The largest group of language instructors from primary and secondary level reported using L1 to almost the same extent (54\% and 53.8\% respectively), and university FL instructors followed them closely with a slightly smaller share $(45.2 \%)$. However, the respondents from primary and secondary sector also reported using L1 often (33.5\% and $20.5 \%$ respectively), whereas this is not the case with tertiary sector where less, rather than more, L1 is used $(45.2 \%$ of university language instructors use L1 rarely). This finding matches that from the survey on instructor $(\mathrm{N}=20)$ and student $(\mathrm{N}=171)$ perceptions of L1 use at university level in Croatia by Kovačić \& Kirinić (2011) who found that L1 use was perceived as acceptable and justified by $80 \%$ of university instructors and that the majority (45\%) used it sometimes. Many respondents wrote a comment in which they emphasised the level of language ability as the primary criterion for L1 quantity.

Table 4. Frequency of English language instructors' L1 reported use at different educational stages.

\begin{tabular}{|c|c|c|c|c|c|}
\hline $\begin{array}{l}\text { Educational } \\
\text { stage }\end{array}$ & $\begin{array}{l}\text { I use L1 during } \\
\text { EFL instruction. }\end{array}$ & $\mathrm{N}$ & $\%$ & M & SD \\
\hline \multirow{4}{*}{$\begin{array}{l}\text { Primary } \\
(\mathrm{N}=278)\end{array}$} & rarely & 27 & 9.7 & \multirow{4}{*}{3.29} & \multirow{4}{*}{.679} \\
\hline & sometimes & 150 & 54.0 & & \\
\hline & often & 93 & 33.5 & & \\
\hline & always & 8 & 2.9 & & \\
\hline \multirow{5}{*}{$\begin{array}{l}\text { Secondary } \\
(\mathrm{N}=117)\end{array}$} & never & 1 & 0.9 & \multirow{5}{*}{3.04} & \multirow{5}{*}{.770} \\
\hline & rarely & 25 & 21.4 & & \\
\hline & sometimes & 63 & 53.8 & & \\
\hline & often & 24 & 20.5 & & \\
\hline & always & 4 & 3.4 & & \\
\hline \multirow{4}{*}{$\begin{array}{l}\text { Tertiary } \\
(\mathrm{N}=42)\end{array}$} & never & 2 & 4.8 & \multirow{4}{*}{2.44} & \multirow{4}{*}{.709} \\
\hline & rarely & 19 & 45.2 & & \\
\hline & sometimes & 19 & 45.2 & & \\
\hline & often & 2 & 4.8 & & \\
\hline
\end{tabular}

These findings are in keeping with the previous notion about Croatian students having better FL ability at higher educational stages and the assumption that lower FL ability requires more L1 use (Hall \& Cook, 2012). Three respondents who reported never using L1 come from secondary and tertiary sector, where their students' high language ability might allow for complete avoidance of L1. However, if this practice is justified remains in 
question since occasional L1 use is found acceptable at all levels (Auerbach, 1993) including the highest levels of FL development (Cook, 2001). Overall, the reported frequency of L1 use in EFL instruction of the participants in the study confirms the notion that lower language ability requires more frequent L1 use.

Reported percentages of language instructors' L1 use in different academic settings, i.e. types of schools, is presented in Table 5. In tune with previous research on the quantity of L1 in FL classrooms (e.g. Chavez, 2006; Duff \& Polio, 1990; Inbar-Lourie, 2010; Hall \& Cook, 2013; Kim and Elder, 2005), the results point to a variability across all ability levels from almost exclusive FL use in upper grades of primary school, secondary school (grammar and vocational) and university to as high as 90\% of L1 use in lower grades of primary school. The smallest range is reported for university setting by instructors working with students of English language and literature $(1 \%-15 \%)$. This is an expected finding: as already mentioned, these EFL learners are highly proficient, which enables almost exclusive FL use with hardly any need for L1. The highest perceived L1 use (90\%) is reported in working with language beginners (lower primary grades), a finding which resonates well with the suggestion by many about more L1 use with learners of low proficiency (e.g. Antón \& DiCamilla, 1999; Brooks \& Donato, 1994; Butzkamm, 2003; Cole, 1989; Dickson, 1996; Ellis, 1985; Hitotuzi 2006; Nation, 2003; Prodromou 2000; Shimizu, 2006).

Table 5. Perceived use of L1 in EFL classes by language instructors fro different academic settings.

\begin{tabular}{|l|c|}
\hline \multicolumn{1}{|c|}{ SCHOOL TYPE } & L1 USE IN $\%$ \\
\hline lower primary & $10 \%-90 \%$ \\
\hline upper primary & $2 \%-80 \%$ \\
\hline secondary grammar & $1 \%-50 \%$ \\
\hline secondary vocational & $2 \%-80 \%$ \\
\hline university English studies & $1 \%-15 \%$ \\
\hline university - non-English studies & $1 \%-80 \%$ \\
\hline
\end{tabular}

However, it is difficult to understand circumstances when $80-90 \%$ of L1 use in a language lesson might be justified as this much L1 use is an obstacle to FL exposure (Cook, 2001; Littlewood \& Yu, 2011). The high percentages of L1 use in different academic settings reported by study participants in the country context of foreign language learning and minimal input situation is a cause for concern and points to a need for guidelines on principled and informed judgements about optimal L1 use (Littlewood \& Yu, 2011; Macaro, 2009; Turnbull \& Dailey-O'Cain, 2009). Evidently, this presents a pedagogical challenge that requires practical scrutiny. 
4.5.2. RQ2. Is there a relationship between the reported frequency of instructors' L1 use and their attitude to L1 role in FL formal learning setting?

Overall, the participants' responses to the items of the BL1FLI Scale $(\alpha=.85)$ generated a result that indicates a positive attitude from FL instructors' towards the L1 use in formal instructional settings $(\mathrm{N}=406, \mathrm{M}=25.0, \mathrm{SD}=$ 5.585) (Table 6).

Table 6. Descriptive statistics for FL instructors' attitude to L1 use in formal instruction.

\begin{tabular}{|l|c|c|c|c|c|}
\hline BL1FLI Scale & $\mathrm{N}$ & $\min$ & $\max$ & $\mathrm{M}$ & $\mathrm{SD}$ \\
\hline $\begin{array}{l}\text { Attitude to L1 role in EFL } \\
\text { instruction }\end{array}$ & 406 & 8 & 38 & 25.0 & 5.585 \\
\hline
\end{tabular}

A correlational analysis was conducted to explore the relationship between the reported attitude towards L1 use in FL instruction and its frequency. Perhaps unsurprisingly, the result showed that the two variables were significantly correlated, $\mathrm{r}(406)=.49, p<.01$. In other words, the more positive attitude implies more L1 use by the survey respondents, which corroborates results of previous research (see Hall \& Cook, 2013).

\subsubsection{RQ3. To what extent do EFL instructors agree on positive contribu- tions of L1 use in FL development and formal instruction?}

The statements about the role of L1 in FL instruction were meant to generate participants' awareness about a set of predicated positive contributions of L1 use in formal learning settings as suggested by current developments in theory and research on the role of L1 in SLA.

The distribution of the participants' responses to the items on the Scale (Table 7) reveals that the majority agreed about L1 contribution to their students' better understanding of grammar $(68 \%$, item 7$)$, to their teaching efficiency $(60.4 \%$, item 4$)$, and their students' better understanding of vocabulary $(53.9 \%$, item 6$)$. This confirms the theoretical assumptions and empirical findings about L1's role in SLA described earlier in this paper, as well as the finding from the Kovačić and Kirinić (2011) study where $80 \%$ of the surveyed university instructors found the greatest benefit of L1 use to be in ensuring easier comprehension. It also points to an awareness of the respondents that L1 use for these particular pedagogical functions or aims is a significant addition to facilitative instructional processes in FL classroom. Interestingly, however, the belief about positive contribution of L1 for vocabulary comprehension (item 3 ) is closely counterbalanced by those who 
disagreed and avoided expressing their opinion on the subject $(43.9 \%$ altogether). Putting the responses of those who opted for the neutral option aside $(25.7 \%)$, almost a fifth of study participants disagreed with this notion. This deviates from the position that learners need precise meaning to make the most of it (e.g. Butzkamm, 2003; Nation, 2003). The statement about L1 use and vocabulary retention (item 6) yielded similar distribution: whereas one third took a neutral position and close to one fifth believe in its positive effect, half of the respondents (50\%) disagreed with this statement. This too, contradicts research that provides evidence of better retention when L1 is used for presentation and practice of new vocabulary (e.g. Latsanyphone \& Bouangeune, 2009; Ramachandran \& Rahim, 2004; Codina Camó \& Pladevall Ballester, 2015).

Table 7. Beliefs about L1 role in FL class: frequency of response.

\begin{tabular}{|l|c|c|c|c|}
\hline Items on the BL1FLI Scale & $\mathrm{N}$ & $\begin{array}{c}\mathrm{A} \\
\%\end{array}$ & $\begin{array}{c}\mathrm{N} \\
\%\end{array}$ & $\begin{array}{c}\mathrm{D} \\
\%\end{array}$ \\
\hline $\begin{array}{l}\text { 1 L1 use contributes to better time } \\
\text { management. }\end{array}$ & 433 & 34.0 & 24.1 & 40.3 \\
\hline $\begin{array}{l}\text { 2 L1 use makes learners feel more } \\
\text { confident and comfortable. }\end{array}$ & 435 & 39.1 & 26.6 & 33.2 \\
\hline $\begin{array}{l}\text { 3 L1 use contributes to better un- } \\
\text { derstanding of vocabulary. }\end{array}$ & 430 & 53.9 & 25.7 & 18.2 \\
\hline $\begin{array}{l}\text { 4 L1 use contributes to the efficien- } \\
\text { cy of my teaching. }\end{array}$ & 439 & 60.4 & 22.7 & 16.6 \\
\hline $\begin{array}{l}\text { 5 Learners have their L1 at the back } \\
\text { of their mind anyway. }\end{array}$ & 435 & 43.3 & 26.8 & 29.7 \\
\hline $\begin{array}{l}\text { 6 L1 use contributes to longer reten- } \\
\text { tion of vocabulary. }\end{array}$ & 432 & 18.6 & 29.5 & 50.0 \\
\hline $\begin{array}{l}\text { 7 L1 use contributes to better un- } \\
\text { derstanding of grammar. }\end{array}$ & 430 & 68.0 & 16.6 & 13.2 \\
\hline $\begin{array}{l}\text { 8 L1 use helps learners learn Eng- } \\
\text { lish better. }\end{array}$ & 437 & 39.1 & 28.9 & 31.3 \\
\hline
\end{tabular}

Note: A collapses scores for strongly agree and agree; $\mathbf{N}$ stands for neutral and represents scores for neither agree nor disagree; D collapses scores for strongly disagree and disagree.

A detailed breakdown of the distribution data to several other beliefs also revealed controversial results. Two items pertaining to L1 contribution to time management (item 1) and its positive role for student confidence and comfort (item 2) achieved very close rates of agreement and disagreement. The $34 \%$ of participants who agreed that L1 use contributes to better time management are counterbalanced by $40.3 \%$ of those who disagreed. There 
are $39.1 \%$ of those who agreed that there is a positive role of L1 for raising students' confidence and comfort during FL lesson and 33.2\% of those who disagreed about it. Likewise, there is a divide between those who believed or disbelieved in L1 as a tool that helps students learn English better $(39.1 \%$ vs. $31.3 \%$, item 8 ). Further, there are many (43.3\%) who agreed that L1 is continually present in the minds of FL learners during instruction, but there was almost a third of instructors $(29.7 \%)$ who disagreed with it. The picture is further complicated by the fact that nearly one fourth to one third of the respondents opted for the neutral option (neither agree nor disagree) for all of these statements (most notably items 1, 2, 5 and 8), excepting the one about L1 contribution in grammar instruction where the belief of the benefits of L1 is the strongest.

There is a general lack of professional consensus on the L1 contributions to the teaching/learning processes in EFL instruction in Croatia. Majority agreement was reached with respect to positive contributions of L1 use for teaching grammar, comprehension of vocabulary and for efficiency of teaching. Majority disagreement was found with respect to L1 use contributing to longer retention of vocabulary, which is not in accordance with recent empirical findings. Beliefs that include L1 use for affective gains in students, better FL learning in general and better time management yielded close rates of agreement and disagreement as well as high shares of neutral choices. Next, the belief of the beneficial use of L1 since its presence in FL learners' minds cannot be avoided is also an issue of controversy lacking professional consensus. These results may be interpreted as a sign of instructors' confusion and uncertainty about the problem addressed, given the background of the conflicting theoretical positions taken by SLA scholars regarding the use of L1 in FL instructional settings. In the same framework, many neutral choices can be a result of FL instructors' unwillingness, reluctance or even anxiety to share their true beliefs given that L1 has been treated negatively in many FL teacher training courses. It seems rather legitimate to speculate that the results obtained point to many instructors' lack of confidence with respect to acceptability of L1 use, which is evident in a certain misalignment of many instructors' beliefs with current SLA perspectives on multilingual development and translanguaging.

Whatever the reason, it is worth noting that study participants were willing to report often and, at times, very high quantities of L1 use in their teaching. This paradox is found elsewhere in research on L1 use in FL learning settings (Hall \& Cook, 2013). If we assume that the results are influenced by instructors' uneasiness in expressing their true beliefs, this may be a sign that monolingual teaching has been an unchallenged assumption for too long (Hall \& Cook, 2012) and that instructors lack knowledge about the positive contributions of L1 in ISLA. The respondents' reaction to the L1 benefits 
implied in the belief statements might have been that of apprehension since it has been suggested elsewhere that many currently practicing FL teachers were trained and educated to avoid L1 and adhere to monolingual teaching practices (Meier, 2016). Whatever the reason, the fact that only responses to two out of eight items revealed majority agreement (over 60\%) implies that close rates of agreement and disagreement and even distributions of responses across the BL1FLI scale require further inquiry in the Croatian context of EFL instruction.

Since beliefs are understood as situationally variable, as suggested earlier in this article, L1 use may be very much related to linguistic and sociocultural contexts of instruction (i.e. programme aims, contents and teaching approaches, learners' background knowledge, learners' L1, etc.), all of which contribute to the choices that instructors make about L1 use suitability and its genuine necessity. There are instructional contexts and instances when L1 use is acceptable and necessary, and others, when the benefits of L1 use are of questionable nature. For example, ESP courses by default require plenty of L1 use, usually in the form of different activities incorporating translation, as opposed to general language courses where translation activities are much less common and usually serve different purposes. Having said that, instructors' education and training, age, teaching experience and teaching context may influence their beliefs of the benefits of L1 use. This assumption was tested to obtain answers to the next research question.

\subsubsection{RQ4. Is the instructors' attitude towards L1's role in FL formal learn- ing setting influenced by their age, teaching experience, instructional setting and/or learner ability?}

To understand instructors' beliefs about L1's role in ISLA it was necessary to investigate if they were related to specific background variables such as their age, professional context and experience and the language ability of their learners. Several analyses of variance were conducted with total scores on the BL1FLI Scale (interpreted as the overall attitude to L1 role in formal EFL learning) and groupings of survey respondents that represented different years of teaching experience (3 to 4 groups), instructors' age ( 3 to 4 groups), teaching context (urban vs. suburban vs. rural areas) and teaching level (primary vs. secondary vs. tertiary). There was no significant difference in the attitude towards L1 between EFL instructors with variable years of teaching experience, a finding shared by the Paker \& Karaağaç (2015) study, between EFL instructors of different age, and EFL instructors from different teaching contexts. The only significant result was found between instructors working at three different educational levels $(F(2,402)=6.49, \mathrm{p}=.002)$. Post hoc comparisons using the Games-Howell test indicated that the mean score of 
primary school instructors $(M=25.63, S D=5.050)$ was significantly different from the mean score of university instructors $(M=22.32, S D=6.051)$. The educational stage, which is interpreted as learner ability in the context of this study, proved to be a factor that influenced instructors' beliefs about the benefits of L1 use in formal instruction, a finding which further corroborates the notion about the level of learner language proficiency as an important factor for interpretation of L1 role in ISLA (see section 3.).

\section{Conclusion}

Theories and models of SLA used to treat learners' L1 as a source of negative transfer that makes optimal L2 development difficult. Current understandings of language processing and meaning making give importance to the role of L1 and all languages-related background and experience of L2 learners in the process of new language acquisition. However, little is known about the manner in which shifts in SLA theory transfer into its applied context and inform L2 formal instruction. Beliefs about SLA refer to language and its learning and, importantly, they are thought to drive action and influence instructional practices of language teachers (Barcelos, 2003).

This paper reports on a study of instructors' perceptions concerning the role of L1 use in ISLA. It is motivated by the fact that FL teachers' daily work turns translanguaging into practice. Hence, beliefs about L1 role in FL instruction are assumed to impact formal settings by facilitating or undermining FL learning and teaching.

The attitude towards L1 role in formal FL learning of Croatian EFL instructors who took part in the study tends to be, on the whole, positive. However, there is evidence of a mismatch between new understandings of the role of L1 and instructor's beliefs and this may reflect conflicting theoretical perspectives in SLA theory. Fairly large groups of respondents seem to be either apprehensive about expressing their opinion or unconvinced of the positive L1 contribution to the teaching/learning process. Paradoxically, notable amounts of L1 use were reported, which means that, clearly, English is not the only language of FL classroom interaction and Croatian EFL context is far from being monolingual. Moreover, given its range and extent, issues related to quantity of target language input available to EFL learners might be a cause for concern. Further, the study provided evidence of the positive relationship between perceived amounts of L1 and an attitude to the benefits of L1 use. Next, the study also substantiates previous findings that pointed at learner language ability as a factor of strong influence on the use of L1 in instructional settings. 
The documented lack of stronger convictions of L1 benefits is believed to have strong implications for professional preparation and continuing development of language instructors as they, evidently, need more theoretical and practical knowledge about L1 use in formal contexts. FL instructors' beliefs should be brought out in the open and challenged (Donaghue, 2003) in hope of facilitating change over time. However, influence of training and education proved to be less important than behaviour internalized through watching others' teach (e.g. Peacock, 2001). All non-native EFL instructors in Croatia have personal experience of the EFL acquisition process. Interestingly, the study showed that their beliefs about L1 role in the EFL development of their learners in formal settings may be quite varied. Therefore, more work is needed to find ways to facilitate or influence existing beliefs, change incorrect ones or create new beliefs about L1 contributions for optimal learning and teaching of EFL.

On a more practical side, the results of this study are of interest for preservice and in-service FL instructors, those who train them and those responsible for their continuous development, as well as those who evaluate them. The important implication is that Croatian EFL instructors need more training in SLA notions relevant to L1's role as well as in effective pedagogical principles that will convince them of its suitability for EFL classrooms. To this end, the development of bilingual/multilingual classroom norms and guidelines should be contextually-embedded and adapted to challenges and circumstances of local EFL settings. Additionally, addressing the controversial issue of L1 in ISLA with EFL instructors would help bridge the gap that was found between their beliefs and the current SLA theory and research about L1 use in formal EFL instruction in Croatia.

There are several limitations to this study that have to be kept in mind. One concern is the representativeness of the sample since the questionnaire was administered electronically via email, which may limit the strength of the findings. The sample was made up of those willing to participate, with the implication that those without technological access, those who use the Internet irregularly or those who simply chose not to take part in the study were excluded. Another concern is the limited focus of the study which is concentrated on the advantages of L1 use in formal language learning settings. Further, questionnaires as research instruments have their advantages and limitations, which have been widely documented (e.g. Hall \& Cook, 2013; Barcelos, 2003). For example, the instrument applied in the study collects quantitative data in a study regarding a construct which is of a rather qualitative nature by itself. Next, the instrument is designed to record respondents' perceptions of L1 use in ISLA (not actual classroom interaction data), whereby honesty of the respondents cannot be validated. Although limitations of the questionnaire as a means of data collection are intrinsic to 
it, the advantages of gathering large amounts of data efficiently from a significant number of subjects are assumed to justify its use for the particular aims of the present study.

Future research needs to rely on multiple data collections and address cause-and-effect relationships between beliefs and practices, i.e. if they are connected and how, as beliefs about L1 in this study were not examined in relation to practice. However, according to Borg (2003), analysis solely based on instructors' beliefs can provide a useful basis for further inquiry. In the Croatian context of formal FL instruction there is a need for evidence of a well-established connection between beliefs and educational practice found in research on teacher cognition. An additional value would be an exploration of the relationship between beliefs, practices and learning outcomes. Moreover, research that includes both instructors' and students' perspectives would be a great asset to the current ISLA understandings in the local, i.e. Croatian, context. Such work will surely help transform the use of L1 (and/or other languages) in the FL instruction into learner-friendly practices that aid EFL progress and achievement in most a favourable way.

\section{References}

Antón, Marta, Frederick J. DiCamilla (1999). Socio-cognitive functions of L1 collaborative interaction in the L2 classroom. The Modern Language Journal 83(2): 233247.

Atkinson, David (1987). The mother tongue in the classroom: A neglected resource? ELT Journal 41(4): 241-247.

Auer, Peter, Li Wei (2007). Introduction: Multilingualism as a problem? Monolingualism as a problem? Auer, Peter, Li Wei, eds. Handbook of Multilingualism and Multilingual Conversation. Berlin - New York: Mouton de Gruyter, 1-12.

Auerbach, Elsa R. (1993). Reexamining English Only in the ESL classroom. TESOL Quarterly 27(1): 9-32.

Barcelos, Ana Maria F. (2003). Researching beliefs about SLA: A critical review. Kalaja, Paula, Ana Maria Ferreira Barcelos, eds. Beliefs about SLA: New Research Approaches. Dortrecht: Springer, 7-33.

Bateman, Blair E. (2008). Student teacher's attitudes and beliefs about using the target language in the classroom. Foreign Language Annals 41(1): 11-28.

Beckner, Clay, Richard Blythe, Joan Bybee, Morten H. Christiansen, William Croft, Nick C.Ellis, John Holland, Jinyun Ke, Diane Larsen-Freeman, Tom Schoenemann (2009). Language is a complex adaptive system. Language Learning 59(S1): 1-26.

Bernat, Eva (2007). Bridging the gap: Teachers' and learners' diversity of beliefs in SLA. Paper presented at the 20th English Australia Education Conference Diversity: A Catalyst for Innovation. Sydney, September 14-16, 2007. 
Borg, Simon (2003). Teacher cognition in language teaching: A review of research on what language teachers think, know, believe and do. Language Teaching 36.2: 81-109.

Brooks, Frank B., Richard Donato (1994). Vygotskyan approaches to understanding foreign language learner discourse during communicative tasks. Hispania 77: 262-274.

Burden, Peter (2000). The use of the students' mother tongue in monolingual English 'conversation' classes at Japanese universities. TLT Online Editor. http:// www. jalt-publications.org/tlt/articles/2000/06/burden [14 February 2009].

Butzkamm, Wolfgang (2003). We only learn language once. The role of the mother tongue in FL classroom: death of a dogma. The Language Learning Journal 28(1): 29-39.

Canagarajah, Suresh (2013). Translingual Practice: Global Englishes and Cosmopolitan Relations. London and New York: Routledge.

Canagarajah, Suresh (2014). In search of a new paradigm for teaching English as an international language. TESOL Journal 5(4): 767-785.

Carless, David (2004). Issues in teachers' reinterpretation of a task-based innovation in primary schools. TESOL Quarterly 38(4): 639-662.

Chavez, Monika (2003). The diglossic foreign-language classroom: Learners' views on L1 and L2 functions. Blyth, Carl S., ed. The Sociolinguistics of ForeignLanguage Classrooms: Contributions of the Native, the Near-native, and the Nonnative Speaker. Boston: Thomson-Heinle, 163-205.

Chavez, Monika (2006). Classroom-language use in teacher-led instruction and teachers' self-perceived roles. International Review of Applied Linguistics 44: 49102.

Codina Camó, Aïda, Elisabet Pladevall Ballester (2015). The effects of using L1 translation on young learners' foreign language vocabulary learning. ELIA 15: 109134.

Cohen, Andrew D. (1998). Strategies in Learning and Using a Second Language. Harlow, Essex: Longman.

Cole, Simon (1998). The use of L1 in communicative English classrooms. http:// www.jalt-publications.org/tlt/files/98/cec/cole.html [7 July 2008].

Cook, Vivian (1997). Monolingual bias in second language acquisition research. The Canadian Modern Language Review 34: 35-50.

Cook, Vivian (2001). Using the first language in the classroom. The Canadian Modern Language Review 57(3): 402-423.

Cook, Vivian (2008). Second Language Learning and Language Teaching. London: Hodder Education.

Cook, Vivian (2010). The relationship between first and second language acquisition revisited. Macaro, Ernesto, ed. The Continuum Companion to Second Language Acquisition. Continuum International Publishing Group, 137-157.

Crawford, Jane (2004). Language choices in the foreign language classroom: Target language or the learners' first language. RELC 35(2): 5-20.

Creese, Angela, Adrian Blackledge (2010). Translanguaging in the bilingual classroom: A pedagogy for learning and teaching? The Modern Language Journal 94(1): 103-115. 
Cummins, Jim (1979). Cognitive/Academic language proficiency, linguistic interdependence, the optimum age question and some other matters. Working Papers on Bilingualism 19: 198-205.

Cummins, Jim (2001). Bilingual children's mother tongue: Why is it important for education? Sprogforum 9: 15-20. http://www.lavplu.eu/central/bibliografie/ cummins_eng.pdf [17 September 2018].

Cummins, Jim (2007). Rethinking monolingual instructional strategies in multilingual classrooms. Canadian Journal of Applied Linguistics 10(2): 221-240.

De Bot, Kees, Wander Lowie, Marjolijn Verspoor (2007). A Dynamic Systems Theory approach to second language acquisition. Bilingualism: Language and Cognition 10(1): 7-21.

Dickson, Peter (1996). Using the Target Language: A View from the Classroom. Slough, Berkshire: National Foundation for Educational Research.

Donaghue, Helen (2003). An instrument to elicit teachers' beliefs and assumptions. ELT Journal 57(4): 344-351.

Duff, Patricia A., Charlene G. Polio (1990). How much foreign language is there in the foreign language classroom? The Modern Language Journal 74(2): 154-166.

Dujmović, Mauro (2007). The use of Croatian in the EFL classroom. Metodički obzori 2(1): 91-101.

Ellis, Rod (1985). Teacher-pupil Interaction in Second Language Development. Gass, Susan M., Carolyn Madden G., eds. Input in second language acquisition. Rowley, MA: Newbury House, 69-88.

Ellis, Rod (1994). The Study of Second Language Acquisition. Oxford: OUP.

Ellis, Rod (2000). Instructed Second Language Acquisition: Learning in the Classroom. Oxford UK \& Cambridge USA: Blackwell Publishers Ltd.

Ferrer, Vincent (2002). The mother tongue in the classroom: Cross-linguistic comparisons, noticing and explicit knowledge. http://www.teachenglishworldwide. com/Articles.htm [5 September 2010].

Firth, Alan, Johannes Wagner (1997). On discourse, communication, and (some) fundamental concepts in SLA research. The Modern Language Journal 81(3): 285-300.

Gabrielatos, Costas (2001). L1 use in ELT: Not a skeleton but a bone of contention - A response to Prodromou. TESOL Greece Newsletter 70: 6-9. http:/ / www. gabrielatos.com/L1UseInELT-TGNL.pdf [27 April 2005].

Guthrie, Larry F. (1984). Contrasts in teachers' language use in a Chinese-English bilingual classroom. J. Handscombe, Jean, Richard A. Orem, Berry P. Taylor, eds. On TESOL '83: The Question of Control. Washington, D. C.: TESOL, 39-52.

Hall, Graham, Guy Cook (2012). Own-language use in language teaching and learning: State of the art. Language Teaching 45(3): 271-308.

Hall, Graham, Guy Cook (2013). Own-language Use in ELT: Exploring Global Practices and Attitudes in ELT. London: British Council.

Herdina, Phillip, Ulrike Jessner (2002). A Dynamic Model of Multilingualism: Perspectives of Change in Psycholinguistics. Clevedon - Buffalo - Toronto - Sydney: Multilingual Matters.

Hitotuzi, Nilton (2006). The learner's mother tongue in the L2 learning-teaching symbiosis. Profile 7: 161-171.

Inbar-Lourie, Ofra (2010). English only? The linguistic choices of teachers of young EFL learners. International Journal of Bilingualism 14(3): 351-367. 
Iyitoglu, Orhan (2016). Code-switching from L2 to L1 in EFL classrooms. Croatian Journal of Education 18(1): 257-289.

Jacobson, Rodolfo, Christian Faltis (eds.) (1990). Language Distribution Issues in Bilingual Schooling. Clevedon - Philadelphia: Multilingual Matters Ltd.

Januliené, Aušra (2008). On the use of L1 in communicative adult EFL classroom. Studies about Languages 13: 77-81.

Kelleher, Mark (2013). Overcoming the first language taboo to enhance learning a foreign language. Procedia - Social and Behavioral Sciences 93: 2037-2042.

Kim, Sun Hee Ok, Catherine Elder (2005). Language choices and pedagogic functions in the foreign language classroom: a cross-linguistic functional analysis of teacher talk. Language Teaching Research 9.4: 355-380.

Kovačić, Andreja, Valentina Kirinić (2011). To use or not to use: First language in tertiary instruction of English as a foreign language. Akbarov, Azamat, ed. Proceedings to 1st International Conference on Foreign Language Teaching and Applied Linguistics. Sarajevo, 150-160.

Kramsch, Claire (ed.) (2002). Language Acquisition and Language Socialization: Ecological Perspectives. London - New York: Continuum.

Kroll, Judith. F., Jason W. Gullifer, Eleonora Rossi (2013). The multilingual lexicon: The cognitive and neural basis of lexical comprehension and production in two or more languages. Annual Review of Applied Linguistics 33: 102-127.

Lantolf, James (ed.) (2000) Sociocultural Theory and Second Language Learning. Oxford: OUP.

Larsen-Freeman, Diane (1997). Chaos/Complexity science and second language acquisition. Applied Linguistics 18.2: 141-165.

Larson-Hall, Jenifer S. (2008). Weighing the benefits of studying a foreign language at a younger age in a minimal input situation. Second Language Research 24(1): 35-63.

Latsanyphone, Soulignavong, Souvannasy Bouangeune (2009). Using L1 in teaching vocabulary to low English proficiency level students: A case study at the National University of Laos. English Language Teaching 2(3): 186-193.

Lee, Jang Ho, Ernesto Macaro (2013). Investigating age in the use of L1 or English only instruction: Vocabulary acquisition by Korean EFL learners. The Modern Language Journal 97(4): 887-901.

Levine, Glenn S. (2003). Student and instructor beliefs and attitudes about target language use, first language use, and anxiety: Report of a questionnaire study. The Modern Language Journal 87(3): 343-364.

Levine, Glenn S. (2011). Code Choice in the Language Classroom. Bristol - Buffalo - Toronto: Multilingual Matters.

Lewis, Gwyn, Bryn Jones, Colin Baker (2012). Translanguaging: Developing its conceptualisation and contextualisation. Educational Research and Evaluation 18: 116.

Lin, Angel M. Y. (1990). Teaching in two tongues: Language alternation in foreign language classrooms. Research Report No. 3. Hong Kong City Polytechnic, Dept. of English. ED399799. http://www.eric.ed.gov/ERICWeb Portal/contentdelivery/servlet/ERICServlet?accno=ED399799. [16 September 2008]

Littlewood, William, Baohua Yu (2011). First language and target language in the foreign language classroom. Language Teaching 44(): 64-77. 
Lowie, Wander, Rika Plat, Kees De Bot (2014). Pink Noise in Language Production: A Nonlinear Approach to the Multilingual Lexicon. Ecological Psychology 26: 216-228.

Ma, Lai Ping Florence (2019). Examining the functions of L1 use through teacher and student interactions in an adult migrant English classroom. International Journal of Bilingual Education and Bilingualism 22(4): 386-401.

Macaro, Ernesto (1997). Target Language, Collaborative Learning and Autonomy Modern Languages in Practice. Clevedon - Philadelphia - Toronto - Adelaide - Johannesburg: Multilingual Matters.

Macaro, Ernesto (2001). Learning Strategies in Foreign and Second Language Classrooms. London - New York: Continuum.

Macaro, Ernesto (2009). Teacher use of codeswitching in the second language classroom: Exploring 'optimal' use. Turnbull, Miles, Jennifer Daily- O'Cain, eds. First Language Use in Second and Foreign Language Learning. Bristol: Multilingual Matters, 35-49.

May, Stephen (ed.) (2013). The Multilingual Turn: Implications for SLA, TESOL and Bilingual Education. Routledge: New York - London.

Meier, Gabriela S. (2016). The multilingual turn as a critical movement in education: Assumptions, challenges and a need for reflection. Applied Linguistics Review 8(1): 131-161.

Milk, Robert D. (1982). Language use in bilingual classrooms: Two case studies. Hines, Mary, William Rutherford, eds. On TESOL '81: Selected Papers from the Annual Conference of Teachers of English to Speakers of Other Languages. Washington, D. C.: TESOL, 181-191.

Milk, Robert D. (1984). A Comparison of the functional distribution of language in bilingual classrooms following language separation vs. concurrent instructional approaches. Paper presented at the Annual Meeting of the American Educational Research Association (68 ${ }^{\text {th }}$, New Orleans, LA, April 25, 1984). ED243331. http://www.eric.ed.gov/ERICWebPortal/contentdelivery/serv let/ERICServlet?accno=ED243331 [15 January 2009].

Mitchell, Rosamond (1988). Communicative Language Teaching in Practice. London: CILT.

Muñoz, Carmen (2008). Symmetries and asymmetries of age effects in naturalistic and instructed L2 learning. Applied Linguistics 29(4): 578-596.

Nagy, Krisztina (2009). English language teaching in Hungarian primary schools with special reference to the teacher's mother tongue use. (Unpublished doctoral dissertation). The Stirling Institute of Education/ University of Stirling. https://dspace.stir.ac.uk/handle/1893/1688 [3 June 2010].

Nagy, Krisztina, Daniel Robertson (2009). Target language use in English classes in Hungarian primary schools. Turnbull, Miles, Jennifer Dailey-O'Cain, eds. First Language Use in Second and Foreign Language Learning. Toronto: Multilingual Matters, 66-86.

Nakayama, Noriko (2002). Factors affecting target language use in the classroom. Bulletin of the Graduate School of Education, Hiroshima University, Part II, Arts and Science Education 51: 207-215. https://ci.nii.ac.jp/els/contents11000097 1505.pdf?id=ART0001144758 [15 July 2008].

Nation, Paul (2003). The role of the first language in foreign language learning. Asian EFL Journal 5(2): 1-8. 
Nazary, Mustafa (2008). The role of L1 in L2 acquisition: Attitudes of Iranian university students. Novitas-Royal 2(2): 138-153.

Nikolov, Marianne, Jelena Mihaljević Djigunović (2011). All shades of every color: An overview of early teaching and learning of foreign languages. Annual Review of Applied Linguistics 31: 95-119.

Paker, Turan, Özlem Karaağaç (2015). The use and functions of mother tongue in EFL classes. Procedia - Social and Behavioral Sciences 199: 111-119.

Pajares, Frank M. (1992). Teacher beliefs and educational research: Cleaning up a messy construct. Review of Educational Research 62.(3): 307-332.

Pavičić Takač, Višnja, Nives Berka (2014). Motivation in foreign language learning: A look at type of school environment as a contextual variable. Explorations in English Language and Linguistics 2(2): 77-103.

Peacock, Matthew (2001). Pre-service ESL teachers' beliefs about second language learning: A longitudinal study. System 29(2): 177-195.

Phillipson, Robert (1992). Linguistic Imperialism. Oxford: Oxford University Press.

Polio, Charlene, Patricia A. Duff (1994). Teachers' language use in university foreign language classrooms: A qualitative analysis of English and target language alternation. The Modern Language Journal 78(3): 313-326.

Prodromou, Luke (2000). From mother tongue to other tongue: What is the place of the student's mother tongue in the EFL classroom? TESOL Greece Newsletter 67. http://www.tesolgreece.com/index.html [7 April 2005].

Radišić, Mirna (2009). Upotreba prvog jezika u nastavi stranog jezika u prošlosti i danas/ L1 use in FL instruction in the past and present. Paper presented at 23 International conference Space and Time in Language: Language in Space and Time. Osijek, 21-23 May 2009.

Radišić, Mirna (2013). Jezični unos i rano ovladavanje engleskim kao stranim jezikom/Language input and early acquisition of English as a foreign language (Unpublished doctoral dissertation). Zagreb: University of Zagreb.

Ramachandran, Sharimllah Devi, Hajar Abdul Rahim (2004). Meaning recall and retention: The impact of the translation method on elementary level learners' vocabulary learning. RELC Journal 35(2): 161-178.

Raschka, Christine, Peter Sercombe, Huang Chi-Ling (2009). Conflicts and tensions in codeswitching in a Taiwanese EFL classroom. International Journal of Bilingual Education and Bilingualism 12(2): 157-171.

Rolin-Ianziti, Jeanne (2003). Justifying selected uses of the learners first language in the foreign language classroom within communicative language teaching. Setting the Agenda: Languages, Linguistics and Area Studies in Higher Education, Manchester, United Kingdom, 24-26 June 2002. London, United Kingdom: CILT, The National Centre for Languages. https://www.llas.ac.uk/resources /paper/1428.html [30 August 2018].

Rolin-Ianziti, Jeanne, Siobhan Brownlie (2002). Teacher use of learners' native language in the foreign language classroom. The Canadian Modern Language Review 58(3): 402-426.

Schmitt, Norbert (1997). Vocabulary learning strategies. Schmitt, Norbert, Michael McCarthy, eds. Vocabulary: Description, Acquisition and Pedagogy. New York: Cambridge University Press, 199-227. 
Schweers, C. William (1999). Using L1 in the L2 classroom. Forum 37/2. http://exchanges.state.gov/forum/vols/vol37/no2/p6.htm [24 September 2008].

Shimizu, Makiko (2006). Monolingual or bilingual Policy in the Classroom: Pedagogical implications of L1 use in the Japanese EFL classroom. www.kyoai.ac. jp/college/ronshuu/.../shimizu.pdf [22 October 2008].

Swain, Merrill, Sharon Lapkin (2000). Task-based second language learning: The uses of the first language. Language Teaching Research 4(3): 251-274.

Tang, Jinlan (2002). Using L1 in the English classroom. English Teaching Forum 40/1. http://exchanges.state.gov/forum/vols/vol40/no1/p36.htm [8 July 2008].

Tucker, Richard G. (1999) A global perspective on bilingualism and bilingual education. ERIC Document Reproduction Service No. ED435168. Retrieved from ERIC database. https:/ / eric.ed.gov/?id=ED435168 [16 September 2018].

Turnbull, Miles (2001). There is a role for the L1 in second and foreign language teaching, but... The Canadian Modern Language Review 57(4): 531-540.

Turnbull, Miles, Jennifer Dailey- O'Cain (eds.) (2009) First Language Use in Second and Foreign Language Learning. Bristol: Multilingual Matters.

Wagner, Johannes (2018). Multilingual and multimodal interactions. Applied Linguistics 39(1): 99-107.

Wei, Li (2018). Translanguaging as a practical theory of language. Applied Linguistics 39(1): 9-30.

\title{
Author's address:
}

\author{
Mirna Erk \\ Faculty of Education \\ University of Osijek \\ Cara Hadrijana 10 \\ 31000 Osijek \\ Croatia \\ e-mail: merk@foozos.hr
}

Received: January 29, 2019

Accepted for publication: April 17, 2019 